Braz J Med Biol Res, September 2011, Volume 44(9) 958-965

doi: 10.1590/S0100-879X2011007500110

Triorganotin as a compound with potential reproductive toxicity in mammals

V.S. Delgado Filho, P.F.I. Lopes, P.L. Podratz and J.B. Graceli

The Brazilian Journal of Medical and Biological Research is partially financed by

\section{虽CNPq}

da Ciência e Tecnologia

Institutional Sponsors

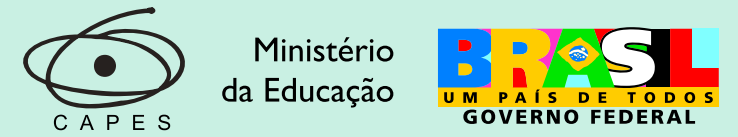

UM PAIS DE TODO
GOVERNO FEDERAL

Q FAPESP

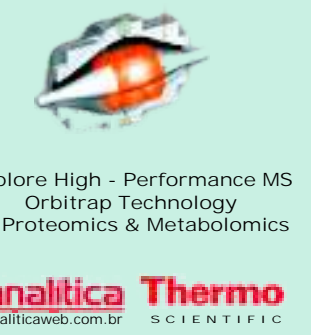

analitica Thermo

$\oplus$ SHIMADZu

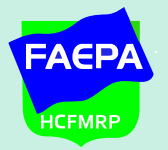

UNICAMP

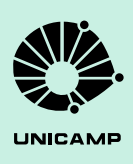

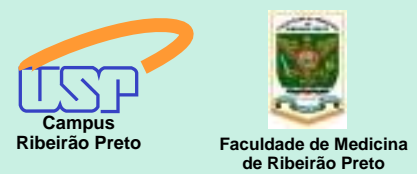

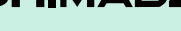

(2)




\title{
Triorganotin as a compound with potential reproductive toxicity in mammals
}

\author{
V.S. Delgado Filho, P.F.I. Lopes, P.L. Podratz and J.B. Graceli
}

${ }^{1}$ Laboratório de Biologia Celular do Envelhecimento, Departamento de Morfologia, Centro de Ciências da Saúde, Universidade Federal do Espírito Santo, Vitória, ES, Brasil

\begin{abstract}
Organotin compounds are typical environmental contaminants and suspected endocrine-disrupting substances, which cause irreversible sexual abnormality in female mollusks, called "imposex". However, little is known about the capability of triorganotin compounds, such as tributyltin and triphenyltin, to cause disorders in the sexual development and reproductive functions of mammals, including humans and rodents. Moreover, these compounds can act as potential competitive inhibitors of aromatase enzyme and other steroidogenic enzymes, affecting the reproductive capacity of male and female mammals. In this review, we discuss the cellular, biochemical, and molecular mechanisms by which triorganotin compounds induce adverse effects in the mammalian reproductive function.
\end{abstract}

Key words: Tributyltin; Triphenyltin; Endocrine disruptor; Aromatase; Imposex; Mammalian reproductive organs

\section{Introduction}

Organotin (OT) compounds such as tributyltin (TBT) and triphenyltin (TPT) have been widely used as biocides, agricultural fungicides, wood preservatives, and disinfecting agents in circulating industrial cooling waters, as well as in antifouling paints for marine vessels (1). Due to the widespread use as antifouling agents in boat paints, OT are a common contaminant of marine and freshwater ecosystems, exceeding acute and chronic toxicity levels (2). Organotin compounds are among the most commonly found pesticides in marine and freshwater environments and consequently their environmental levels, fate and toxicity are of current concern $(1,2)$. The general formula of OT is $R_{n} S_{n} X_{4-n}$, where $R$ is an alkyl or aryl group, $X$ is an anion or anionic species such as chloride, fluoride, oxide, hydroxide, acetate, or other functional group, and "n" represents the amount of organic radical (represented by " $\mathrm{R}_{\mathrm{n}}$ ") or inorganic radical (represented by " $\mathrm{X}_{4-n}$ ") that will bind to form organotin; " $n$ " varies from 1 to 4 radicals. OT compounds can belong to any of four classes related to the number of organic groups, namely tetraorganotins, triorganotins, diorganotins, and monoorganotins (3).

There are many reports of the biological effects of OT, including a wide range of toxic effects on eukaryotes $(1,4,5)$. These compounds are potent endocrine-disrupting chemicals against marine invertebrates (6), mainly, but not exclusively, against gastropod mollusks. An endocrine disruptor is an exogenous substance or mixture that alters the function(s) of the endocrine system and consequently causes adverse health effects in an intact organism, or its progeny, or (sub)population by disrupting the hormonal balance and resulting in developmental and reproductive abnormalities (3). For example, very low concentrations of TBT and TPT induce irreversible sex-organ alterations in female mollusks, a phenomenon known as "imposex" (7). These endocrine abnormalities are the result of a masculinization process by which male sex organs are developed, notably a penis and a vas deferens, in female animals, which can lead to sterility and death of affected females (8) (Figure 1). In certain species, growth of a vas deferens disrupts the structure and function of oviducts, impairing normal breeding activity and causing a population decline (2). In addition, imposex has been reported in more than 190 marine species $(2,8)$ and has been considered to be the most important endocrine disruption effect derived from a specific class of compounds (7). This syndrome is, therefore, a useful biomarker of organotin pollution (9-11). Besides affecting gastropods, organotins are also considered to be responsible for inducing hormonal alterations in bivalve

Correspondence: J.B. Graceli, Departamento de Morfologia, Centro de Ciências da Saúde, Universidade Federal do Espírito Santo, Av. Marechal Campos, 1468, 29440-090 Vitória, ES, Brasil. Fax: 55-27-3335-7369. E-mail: jbgraceli@ccs.ufes.br or jbgraceli@gmail.com

Presented at the XV Simpósio Brasileiro de Fisiologia Cardiovascular, São Paulo, SP, Brazil, February 2-5, 2011.

Received February 11, 2011. Accepted August 9, 2011. Available online August 26, 2011. Published September 16, 2011. 
mollusks (12), crustaceans (13) and fish (14).

Unfortunately, these OT are also suspected to cause endocrine-disrupting effects in mammals, including humans (15) and rodents $(16,17)$, due in part to their possible transfer through marine food chains and to the consumption of contaminated seafood. Currently, human exposure may come from dietary sources, such as fish and shellfish, or through contaminated drinking water (18).

In in vitro studies, exposure of the human choriocarcinoma cell lines to $300 \mathrm{nM}$ TBT or TPT markedly decreased DNA and protein synthesis (19). In the same concentration ranges, TPT also inhibited the catalytic activity of human aromatase (20) and other steroidogenic enzymes, affecting sexual development in male $(16,21)$ and female rats (22). Therefore, OT clearly have many complex actions on the endocrine system of both genders, that may be inducing morphological changes in target organs. They also represent a possible risk to human health since hormonal imbalance has been linked to negative outcomes such as declining reproductive health, gonadal cell dysfunction, reduced weight of sex organs, congenital anomalies, and even brain diseases (20).

\section{Organotins as endocrine-disrupting chemicals}

The production of sex steroid hormones from cholesterol requires trafficking between mitochondria and smooth endoplasmic reticulum and involves many enzymatic steps (23). Most of these pathways use cytochrome P450 hemecontaining enzymes. Some OT compounds are known as encoding-disrupting chemicals that change steroid hormone biosynthesis $(7,24)$.

As mentioned above, these OT have been suspected to masculinize reproductive organs in vertebrates because, in some gastropods, very low OT concentrations induce "imposex" (7). Several lines of evidence have led to the theory that these OT act as specific inhibitors of aromatase enzyme, which converts androgen to estrogen $(7,24)$. Exposure to OT increases testosterone levels in female gastropods and OT-induced imposex can be mimicked by specific aromatase inhibitors (24). Additionally, TBT was reported to be catalyzed to dibutytin by aromatase (25). However, it remains unclear whether OT especially inhibits the catalytic activity of aromatase in vertebrates.

In other experiments, butyltins were shown to exhibit structure-related inhibition of the catalytic human aromatase protein from a human placenta cell line (26) or from transfected cells (27). However, at effective concentrations (micromolar level) for the inhibition of aromatase, TBT and TPT are generally toxic to mammalian cells because they cause apoptosis or necrosis $(28,29)$. In the human choriocarcinoma cell lines Jar, JEG-3 and BeWo, exposure to TBT or TPT concentrations higher than $300 \mathrm{nM}$ markedly decreases DNA and protein synthesis $(19,29)$. Concentrations under 1 $\mu \mathrm{M}$ of either OT did not significantly affect aromatase activity in microsomes isolated from human choriocarcinoma cells 
(19). In addition to aromatase, above $1 \mu \mathrm{M}$, TBT inhibits the catalytic activity of human $5 \alpha$-reductase I and II (5a-R I and II) (30), rat $3 \beta$-hydroxysteroid dehydrogenase (3ß-HSD)

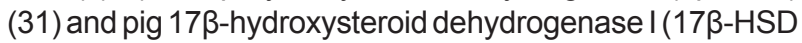
I) (32). TPT also inhibited the catalytic activity of human aromatase, 5a-R II, 17 $\beta-H S D$ I and III (20). These observations suggest that, at low levels, these OT do not specifically inhibit the catalytic activity of aromatase. We should also distinguish between nonspecific OT toxicity to cells and its specific inhibition of steroidogenic enzymes.

Based on endocrine studies, gonadal steroid receptors and steroidogenic enzymes for sex steroid hormones have not yet been identified in gastropods, and it remains unclear whether sex steroid hormones are critical factors for sexual maturation in these animals. Furthermore, homologues of estrogen and androgen receptors have not been found in invertebrates (33) and the composition of nuclear receptor family members is very different between vertebrates and invertebrates (34). Therefore, there is some doubt as to whether OT might function as agonists for nuclear receptors (2) and/or inhibitors of enzymes that metabolize androgens in gastropods, leading us to suspect that OT compounds may affect other target molecules.

\section{Organotins affect endocrine functions in the mammalian gonadal system}

Sexual differentiation is a sequential process beginning with the establishment of chromosomal sex at fertilization, followed by the development of gonadal sex, and culminating in the development of secondary characteristics, collectively termed the male and female phenotypes (35). The endocrine system deeply affects the reproductive morphophysiology, most likely due to specific genes, to the actions of gonadal steroids and of the endocrine/paracrine pathways on the gonadal system (36). Moreover, mainly sex hormones, i.e., estrogen and testosterone, have also been shown to exert different effects on male and female animals, respectively (36), according to the time and dose of toxic exposure to OT. Studies have suggested that the potential toxicity of OT to mammals (humans and rodents) is endocrinopathic, as well as potentially teratogenic and toxic for reproduction (2) in both genders $(16,17,21)$. The data regarding mainly these morphofunctional changes induced in the mammalian reproductive system by some triorganotins are listed in Table 1 in order of effective dose.

\section{Male reproductive system}

Several studies addressing the effect of TBT on male reproductive functions have been reported (16,21,37-44). A study conducted on male rats over two generations showed that testis, epididymis, ventral prostate, and body weight decreased in all groups, but mainly in the group treated with a dietary concentration of $125 \mathrm{mg} \mathrm{TBTCl}$ per g diet (21). No reduction was observed in the weight of the seminal vesicle in the F1 generation, whereas the effects on the F2 generation were greater compared with those observed in F1 (21). However, some investigations have shown a significant decrease in the weight of the seminal vesicle $(16,42)$ and in the weights of all reproductive organs at 15 $\mathrm{mg} \mathrm{TBT/kg}$ body weight (16). Other studies have indicated that the aromatase inhibitor induces a "hyperandrogenic" status in male mammals $(45,46)$. However, atrophy of the ventral prostate was evident in the rats fed the TBTCl diet, which is seemingly contrary to a "hyperandrogenic" status. Moreover, prostatic atrophy caused by aromatase inhibition has been frequently reported $(47,48)$. On the other hand, estrogen is considered to be important for the normal functioning of the prostate, stimulating the expression of androgen receptor (49), and an estrogen receptor antagonist or low serum levels of estrogen also cause atrophy of the prostate (50).

The imposex caused by TBT in some mollusks was attributed to the inhibition of aromatization and conjugation of testosterone (7). Disorders of testosterone aromatization have been linked to serious damage to spermatogenesis, especially spermiogenesis in mice and monkeys $(45,46)$.

Based on histopathological analysis, TBT induces morphofunctional changes in the testes, including vacuolization of seminiferous epithelium, delayed spermiation, spermatid retention into the germinative epithelium and germ cell degeneration near the basement membrane. The frequencies of these impairments in male sex organs were low in the F1 generation, but greater and considered to be abnormal in the TBT-treated F2 generation, although there was a dose-dependent increase in serum testosterone levels of the rats fed TBTCl diets and a decrease in serum estrogen levels in the F1 generation (21). An increase of detached debris and sloughed cells was observed in the tubules of the epididymis and seminal vesicles were narrowed and filled with epithelial cells (42). The count of caudal epididymal and testicular sperm (41) and of homogenization-resistant spermatids decreased (21), and the motility, mean angular displacement, lateral head displacement, and dance of sperm from the vas deferens were also reduced (41).

OT compounds can cross the placental barrier and accumulate in large quantities in the placenta and fetal tissues (51). Recent investigations have demonstrated that OT compounds can accumulate at approximately 5-fold higher levels in the dam's placenta than in her blood. TBT levels where $50 \%$ lower in pups than in the placenta. Also, TBT levels in the liver and brain tissues of pups continued to decline 6 and 12 days after birth even though TBT was transferred via milk. Probably, because of the very low levels of TBT in milk, the concentration was similar to that in the dam's blood, but five times lower than in the placenta (52).

Alarge body of evidence indicates that in utero exposure to OT $(37,39)$ induces a different response pattern in preand postnatal offspring $(37,39,44)$. Kishta et al. (39) reported that pregnant rats receiving TBT by gavage from day 0 to 
day 19 or from day 8 to day 19 of gestation presented, when examined by electron microscopy, lipid droplets in the cytoplasm of Sertoli cells and in gonocytes, and also the presence of larger intercellular spaces and abnormally dilated endoplasmic reticulum in both cells. The number of gonocytes, Sertoli cells and Leydig cells of fetal testis was reduced after in utero exposure to TBTCI (10 and $20 \mathrm{mg} /$ $\mathrm{kg}$ ) from gestational days 0 to 19 and 8 to 19 in pregnant rats. In addition, the fetal ovary presented a large number of germ cells with pyknotic nuclei, typical of degenerating germ cells, suggesting that apoptosis contributed to the decreased number of these cells after TBT exposure (39). In the intertubular region between adjacent interstitial cells, immunostaining for the gap junction protein connexin 43 was strong in controls, whereas it was reduced or completely absent in treated rats. Taken together, these data indicate that cellular communication via Cx43-type gap junctions is decreased following in utero exposure to TBT.

Table 1. Morphofunctional changes induced by triorganotins in the reproductive function of mammals.

\begin{tabular}{|c|c|c|c|}
\hline & \multicolumn{3}{|c|}{ Treatment (dose concentration) } \\
\hline & TBT1 (0-10 mg/kg) & TBT2 (10.1-20 mg/kg) & TPT $(6.0-20 \mathrm{mg} / \mathrm{kg})$ \\
\hline \multicolumn{4}{|l|}{ Females } \\
\hline \multicolumn{4}{|c|}{ Reproductive organ weights (g/body weight) } \\
\hline Uterus & $\downarrow$ & $\downarrow$ & $\downarrow$ \\
\hline Ovary & $\downarrow$ & $\downarrow$ & $\downarrow$ \\
\hline \multicolumn{4}{|l|}{ Histopathology analysis } \\
\hline Ovary (germ cells) & $\downarrow$ & $\downarrow$ & $\uparrow$ Ovarian cyst \\
\hline Follicles (normal mature follicles) & $\downarrow$ & $\downarrow$ & \\
\hline Atretic follicles & $\uparrow$ & $\uparrow$ & $\uparrow$ \\
\hline \multicolumn{4}{|l|}{ In utero effects } \\
\hline Germ cells & $\downarrow$ Number $\uparrow$ Pyknotic nuclei $\uparrow$ Apoptosis & & ND \\
\hline Fetal storage & $\begin{array}{l}\downarrow \text { Female and male body weight on } \\
\text { postnatal days } 6 \text { and } 12\end{array}$ & & NS \\
\hline Aromatase activity & $\begin{array}{l}\downarrow \text { Ovarian rat cells } \downarrow \text { Activity } \\
\downarrow \text { mRNA in KGN cell line }\end{array}$ & & $\downarrow$ Ovarian rat cells \\
\hline Sexual hormone levels & NS & $\downarrow T e \downarrow E_{2}$ & $\downarrow T e \downarrow E_{2} \downarrow P_{4}(\mathrm{DPTCl})$ \\
\hline \multicolumn{4}{|l|}{ Males } \\
\hline \multicolumn{4}{|c|}{ Reproductive organ weights (g/body weight) } \\
\hline Testis & NS & NS & NS \\
\hline Epididymis & $\downarrow$ & $\downarrow$ & ND \\
\hline Prostate & $\downarrow$ & $\downarrow$ & ND \\
\hline Seminal vesicle & NS & $\downarrow$ & $\downarrow$ \\
\hline Histopathology analysis & $\uparrow$ Dysfunction of epithelium (vacuolization) & & $\uparrow$ Atrophy \\
\hline Seminiferous tubules & $\uparrow$ Spermatide retention & $\uparrow$ Delay of maturation & \\
\hline Gonocytes (number) & $\downarrow$ & NS & ND \\
\hline Sertoli cells (number) & $\downarrow$ & $\downarrow$ & NS \\
\hline Leidig cells (number) & NS & ND & ND \\
\hline \multicolumn{4}{|l|}{ In utero effects } \\
\hline Germ cells & $\uparrow$ Degeneration & $\uparrow$ Degeneration & ND \\
\hline Gametes & $\begin{array}{l}\downarrow \text { Number } \uparrow \text { Delay of spermiation } \\
\downarrow \text { Motion kinematic }\end{array}$ & & $\downarrow$ Number \\
\hline Sertoli cells & $\uparrow$ Dysfunction (large intercellular spaces) & & NS \\
\hline Leidig cells & NS & NS & $\uparrow$ Disfunction \\
\hline
\end{tabular}

The table is organized by effective dose. TBT and TPT = tributyltin and triphenyltin, respectively; NS = not significant; ND = not determined; KGN cell line = human granulose-like tumor cell line. The decrease of aromatase activity in KGN cells treated with TBT (20 $\mathrm{ng} / \mathrm{mL}$ for $48 \mathrm{~h}$ ) was related to the decrease of aromatase mRNA levels. Te = testosterone; $\mathrm{E}_{2}=$ estrogen; $\mathrm{P}_{4}=$ progesterone (DPTCl: diphenyltin dichloride, dose: $16.5 \mathrm{mg} / \mathrm{kg}$, in rats on days 4 and 9 of pseudopregnancy). 
Growth retardation, delayed ossification of the fetal skeleton and reduced body weight were also detected in male offspring. Additionally, a reduced testosterone concentration, as well as a significant delay in the age at preputial separation (53) was found after in utero exposure to TBT of rats, without direct effects on the male reproductive system (37). Decreased serum concentrations of thyroxine and triiodothyronine (37) were also observed in another study (43), in association with extensive damage to the thyroid gland, and low expression of thyroid hormone receptor alpha in marine fish testes. Also, exposure caused interstitial fibrosis and pyknotic nuclei. These results implied that inhibition of thyroid status induced by TBT possibly affected testicular development. Similarly, after contact with TBT, the gonadosomatic index decreased in a dose-dependent manner and the level of $17 \beta$-estradiol was decreased and resulted in a down-regulation of estrogen receptor alpha mRNA. This, in association with the increased size of lipid droplets, may contribute to Sertoli cell dysfunction, leading to disrupted spermatogenesis in fish (44). The molecular mechanisms for the formation of these OT-induced lipid inclusions remain enigmatic. They could be due to the potent inhibition of mitochondrial oxidative phosphorylation by TBT and inhibition of fatty acid transport to the mitochondria, with its consequent accumulation in the cytoplasm (39)

In the same line of investigation, in vitro analysis demonstrated that TBT enhanced the chance of the occurrence of Leydig cell apoptosis in a time- and dose-dependent manner (40), probably mediated by increased cytoplasmic $\mathrm{Ca}^{2+}$ concentration and mitochondrial disorders. Immature male mice receiving a single dose of TBT presented a delay in lumen formation in seminiferous tubules and increased numbers of apoptotic germ cells inside the tubules, but not in Leydig cells (40). Reduced serum testosterone levels $(16,40,43,44)$ and down-regulated expression of P450scc (cholesterol side-chain cleavage enzyme complex), P450 (for example, 17 $\alpha$-hydroxylase), $3 \beta-H S D$ and $17 \beta-H S D$ were also observed (38). However, in contrast, another study reported an increase of serum testosterone (21).

\section{Female reproductive system}

The production of germ cells is essential for the continuation of the species. In the female, this function is accomplished by the ovaries. These organs secrete steroid (mainly progesterone and estradiol) and non-steroid hormones (such as relaxin) that not only modulate the secretion of anterior pituitary hormones, but also act on various targets in the organs of the female reproductive system (35).

A large number of studies have shown that exposure to OT and/or OT-contaminated seafood can cause reproductive disruption in the female reproductive system of mammals $(16,17,19,21,22,54-57)$. After treatment with OT, pseudopregnant rats showed a decrease in uterine weight and serum progesterone levels, but ovarian weight, number of corpora lutea and estrogen levels remained at average levels. This was correlated with decreased pregnancy rates and numbers of embryo implantations (56). However, Grote et al. (17) showed that TPT increased the ovarian weight of female rats on postnatal day 53 , but not on postnatal day 33 , suggesting morphofunctional changes.

In mammals, in utero exposure to high doses of TBT led to a decrease in maternal weight gain and fetal weight, induced pre- and post-implantation losses $(37,55,57)$, provoked fetal toxicity (58), altered the anogenital distance of female pups on postnatal day 1 (22), caused precocious completion of vaginal opening in postnatal females (53), reduced by about $45 \%$ the number of germ cells, and induced morphofunctional changes in the ovaries of fetal female rats (39). On the other hand, there were no effects of dibutyltin dichloride on developmental parameters in surviving fetuses, including fetal body weight, crown-rump length, tail length, or placental weight in cynomolgus monkeys. No external, internal, or skeletal malformations were detected in fetuses, suggesting embryolethality, but not teratogenic effects in monkeys $(59,60)$.

On the other hand, in in vitro studies using human placental cells, TBT and TPT increased mRNA and the catalytic activity of aromatase and $17 \beta-\mathrm{HSD}$ I enzymes, which convert low-activity estrone to high-activity estradiol in human choriocarcinoma cells (29) in a dose-dependent fashion following exposure to nontoxic concentration ranges (2), indicating the regulation of mRNA levels of both steroidogenic enzymes. In the human ovary, however, TBT and TPT suppressed both aromatase activity and gene expression in a granulose-like cell line (28). Similar data showed that TPT decreased the ovarian aromatase activity on postnatal day 53 but not on postnatal day 33 in female rats (17). Therefore, this discrepancy may be due to the tissue-specific expression of aromatase, strictly regulated in each cell type (29).

To illustrate the influence of the distribution of triorganotin on the maternal-fetal-placental unit and its effects on the signal transduction pathways in cell metabolism for the down-regulation of reproductive function, Figure 2 provides a diagram of a possible mechanism of the endocrine-disruption effects of OT on the mammalian reproductive system. As observed, triorganotin compounds can be absorbed from the maternal circulation through the placenta, accumulating in fetal tissues and inducing morphological changes. When triorganotins cross the cell membrane they could bind to nuclear receptors (NRs), which reside in the cytoplasm (e.g., glucocorticoid receptors) or in the nucleus (e.g., sex hormone receptors). Upon ligand binding, triorganotin-NRs translocate to the nucleus where they form a complex with triorganotin-NRs and co-activators, which binds to response elements on the DNA, and induces transcription of target genes, changes in the expression of some proteins, as well as mitochondrial and cell dysfunctions.

Several studies have revealed that exposure to OT compounds alters development and the sexual param- 


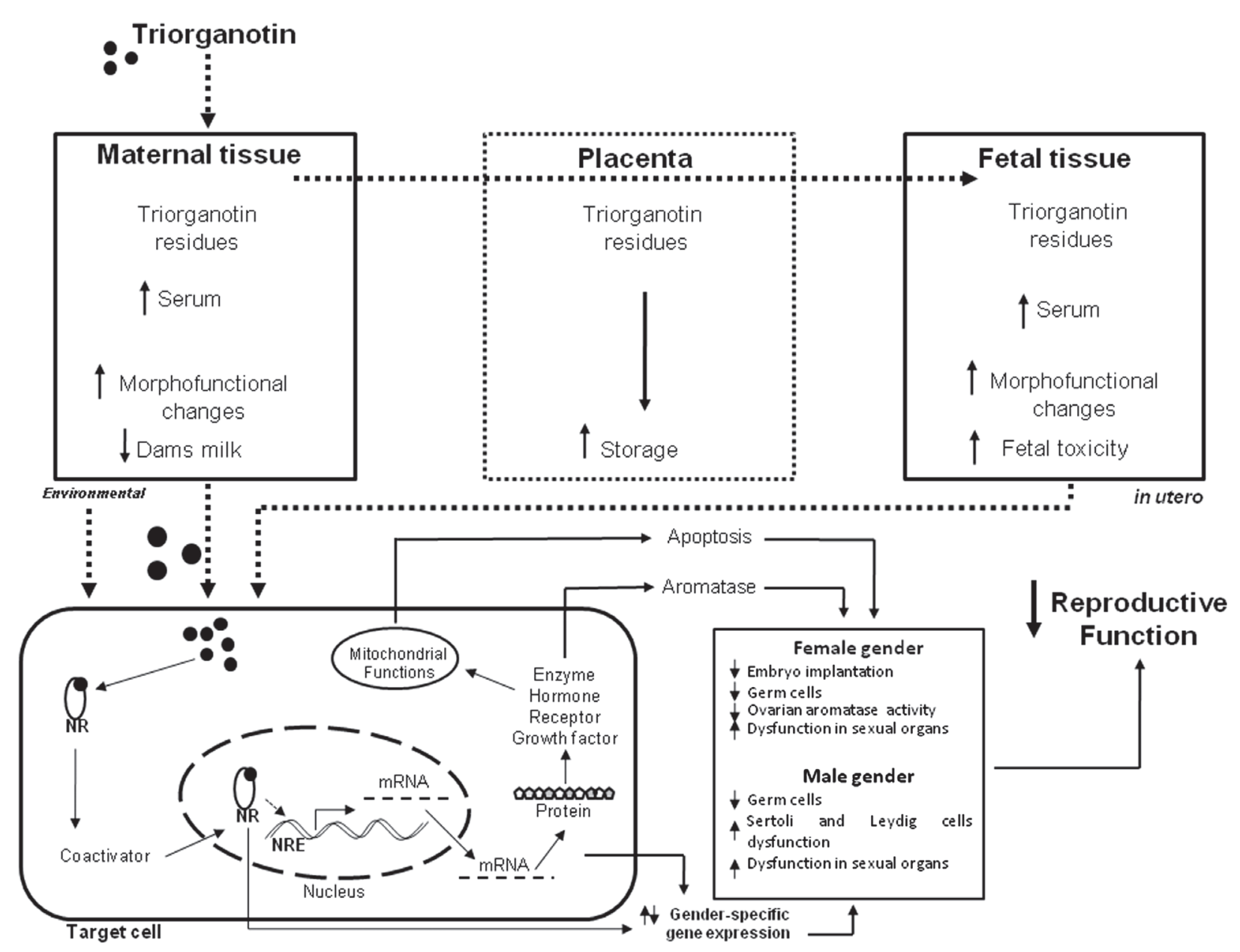

Figure 2. Diagram of triorganotin distribution in the maternal-fetal-placental unit and its effects on signal transduction pathways of cell metabolism affecting reproductive function. NR = nuclear receptor; NRE = nuclear receptor response element. The dashed arrows indicate that triorganotin crosses the maternal-fetal-placental tissues and cell membranes. The continuous arrows indicate a potential signaling pathway through which triorganotin might act to modulate metabolism in target cells and organs.

eters of the reproductive system of gastropods, with these compounds acting as endocrine disruptors and influencing steroid metabolism, mainly by inhibiting the enzymatic activity of aromatase and the development of male sexual characters. These endocrine abnormalities are known as imposex. These compounds may have toxic effects on the endocrine system of mammals, modifying embryo implantation, Sertoli and Leydig cell function, sex organ weight, sex hormones, ovarian aromatase activity in different cell lines and animal models, or changing the activity of other glands such as the thyroid. Moreover, there are other steroidogenic enzymatic pathways that can be impaired by triorganotin. The effects of triorganotins have been associated with gender-specific morphofunctional changes in mammalian reproductive organs. Despite several lines of evidence, further epidemiological, clinical and molecular studies in different human cells and experimental animals are needed to try to understand the toxic effects of OT on the endocrine system of mammals.

\section{Acknowledgments}

Research supported by FAPES (\#45446121/2009-002) and UFES (\#PIVIC 2010-11). 


\section{References}

1. Fent K. Ecotoxicology of organotin compounds. Crit Rev Toxicol 1996; 26: 1-117.

2. Nakanishi T. Endocrine disruption induced by organotin compounds; organotins function as a powerful agonist for nuclear receptors rather than an aromatase inhibitor. $J$ Toxicol Sci 2008; 33: 269-276.

3. Blunden SJ, Evans CJ. The handbook of environmental chemistry. Hutzinger $\mathrm{O}$ (Editor). Berlim: Springer-Verlag; 1990.

4. Takahashi S, Mukai H, Tanabe S, Sakayama K, Miyazaki $\mathrm{T}$, Masuno $\mathrm{H}$. Butyltin residues in livers of humans and wild terrestrial mammals and in plastic products. Environ Pollut 1999; 106: 213-218.

5. Meng PJ, Lin J, Liu LL. Aquatic organotin pollution in Taiwan. J Environ Manage 2009; 90 (Suppl 1): S8-S15.

6. Limaverde AM, Wagener AL, Fernandez MA, Scofield AL, Coutinho R. Stramonita haemastoma as a bioindicator for organotin contamination in coastal environments. Mar Environ Res 2007; 64: 384-398.

7. Matthiessen P, Gibbs PE. Critical appraisal of the evidence for tributyltin-mediated endocrine disruption in mollusks. Environ Toxicol Chem 1998; 17: 37-43.

8. Shi HH, Huang CJ, Zhu SX, Yu XJ, Xie WY. Generalized system of imposex and reproductive failure in female gastropods of coastal waters in mainland China. Mar Ecol Prog Ser 2005; 304: 179-189.

9. Fernandez MA, Limaverde AM, de Castro I, Almeida AC, de Luca Rebello Wagener A. Occurrence of imposex in Thais haemastoma: possible evidence of environmental contamination derived from organotin compounds in Rio de Janeiro and Fortaleza, Brazil. Cad Saúde Pública 2002; 18: 463-476.

10. Fernandez MA, Limaverde AM, Scofield AL, Wagener ALR. Preliminary evaluation of human health risks from ingestion of organotin contained seafood in Brazil. Braz $J$ Oceanogr 2005; 53: 75-77.

11. Fernandez MA, de Luca Rebello Wagener A, Limaverde AM, Scofield AL, Pinheiro FM, Rodrigues E. Imposex and surface sediment speciation: a combined approach to evaluate organotin contamination in Guanabara Bay, Rio de Janeiro, Brazil. Mar Environ Res 2005; 59: 435-452.

12. Siah A, Pellerin J, Amiard JC, Pelletier E, Viglino L. Delayed gametogenesis and progesterone levels in soft-shell clams (Mya arenaria) in relation to in situ contamination to organotins and heavy metals in the St. Lawrence River (Canada). Comp Biochem Physiol C Toxicol Pharmacol 2003; 135: 145-156.

13. Tang $\mathrm{CH}$, Hsu TC, Tsai CW, Wang WH. Characterization of the planktonic shrimp, Acetes intermedius, as a potential biomonitor for butyltin. J Environ Monit 2009; 11: 92-99.

14. Mortensen AS, Arukwe A. Modulation of xenobiotic biotransformation system and hormonal responses in Atlantic salmon (Salmo salar) after exposure to tributyltin (TBT). Comp Biochem Physiol C Toxicol Pharmacol 2007; 145: 431-441.

15. Keithly JC, Cardwell RD, Henderson DG. Tributyltin in seafood from Asia, Australia, Europe, and North America: Assessment of human health risks. Human Ecol Risk Assess 1999; 5: 337-354.
16. Grote K, Stahlschmidt B, Talsness CE, Gericke C, Appel KE, Chahoud I. Effects of organotin compounds on pubertal male rats. Toxicology 2004; 202: 145-158.

17. Grote K, Andrade AJ, Grande SW, Kuriyama SN, Talsness $\mathrm{CE}$, Appel KE, et al. Effects of peripubertal exposure to triphenyltin on female sexual development of the rat. Toxicology 2006; 222: 17-24.

18. Dorneles PR, Lailson-Brito J, Fernandez MA, Vidal LG, Barbosa LA, Azevedo AF, et al. Evaluation of cetacean exposure to organotin compounds in Brazilian waters through hepatic total tin concentrations. Environ Pollut 2008; 156: 1268-1276

19. Nakanishi T, Kohroki J, Suzuki S, Ishizaki J, Hiromori Y, Takasuga $S$, et al. Trialkyltin compounds enhance human CG secretion and aromatase activity in human placental choriocarcinoma cells. J Clin Endocrinol Metab 2002; 87: 2830-2837.

20. Lo S, Allera A, Albers P, Heimbrecht J, Jantzen E, Klingmuller D, et al. Dithioerythritol (DTE) prevents inhibitory effects of triphenyltin (TPT) on the key enzymes of the human sex steroid hormone metabolism. J Steroid Biochem Mol Biol 2003; 84: 569-576.

21. Omura M, Ogata R, Kubo K, Shimasaki Y, Aou S, Oshima Y, et al. Two-generation reproductive toxicity study of tributyltin chloride in male rats. Toxicol Sci 2001; 64: 224-232.

22. Ogata R, Omura M, Shimasaki Y, Kubo K, Oshima Y, Aou S, et al. Two-generation reproductive toxicity study of tributyltin chloride in female rats. $J$ Toxicol Environ Health A 2001; 63 : 127-144

23. Whitehead SA, Rice S. Endocrine-disrupting chemicals as modulators of sex steroid synthesis. Best Pract Res Clin Endocrinol Metab 2006; 20: 45-61.

24. Bettin C, Oehlmann J, Stroben E. TBT-induced imposex in marine neogastropods is mediated by an increasing androgen level. Helgol Meeresunters 1996; 50: 299-317.

25. Lee RF. Metabolism of tributyltin oxide by crabs, oysters and fish. Mar Environ Res 1985; 17: 145-148.

26. Heidrich DD, Steckelbroeck S, Klingmuller D. Inhibition of human cytochrome P450 aromatase activity by butyltins. Steroids 2001; 66: 763-769.

27. Cooke GM. Effect of organotins on human aromatase activity in vitro. Toxicol Lett 2002; 126: 121-130.

28. Saitoh M, Yanase T, Morinaga H, Tanabe M, Mu YM, Nishi $\mathrm{Y}$, et al. Tributyltin or triphenyltin inhibits aromatase activity in the human granulosa-like tumor cell line KGN. Biochem Biophys Res Commun 2001; 289: 198-204.

29. Nakanishi T, Hiromori Y, Yokoyama H, Koyanagi M, Itoh $\mathrm{N}$, Nishikawa J, et al. Organotin compounds enhance 17beta-hydroxysteroid dehydrogenase type I activity in human choriocarcinoma JAr cells: potential promotion of 17 beta-estradiol biosynthesis in human placenta. Biochem Pharmacol 2006; 71: 1349-1357.

30. Doering DD, Steckelbroeck S, Doering T, Klingmuller D. Effects of butyltins on human 5alpha-reductase type 1 and type 2 activity. Steroids 2002; 67: 859-867.

31. McVey MJ, Cooke GM. Inhibition of rat testis microsomal 3beta-hydroxysteroid dehydrogenase activity by tributyltin. J Steroid Biochem Mol Biol 2003; 86: 99-105.

32. Ohno S, Nakajima Y, Nakajin S. Triphenyltin and tributyltin 
inhibit pig testicular 17beta-hydroxysteroid dehydrogenase activity and suppress testicular testosterone biosynthesis. Steroids 2005; 70: 645-651.

33. Escriva H, Delaunay F, Laudet V. Ligand binding and nuclear receptor evolution. Bioessays 2000; 22: 717-727.

34. Escriva H, Safi R, Hanni C, Langlois MC, Saumitou-Laprade $P$, Stehelin $D$, et al. Ligand binding was acquired during evolution of nuclear receptors. Proc Natl Acad Sci U S A 1997; 94: 6803-6808.

35. Filicori M, Santoro N, Merriam GR, Crowley WF Jr. Characterization of the physiological pattern of episodic gonadotropin secretion throughout the human menstrual cycle. J Clin Endocrinol Metab 1986; 62: 1136-1144.

36. Piprek RP. Genetic mechanisms underlying male sex determination in mammals. J Appl Genet 2009; 50: 347-360.

37. Adeeko A, Li D, Forsyth DS, Casey V, Cooke GM, Barthelemy $\mathrm{J}$, et al. Effects of in utero tributyltin chloride exposure in the rat on pregnancy outcome. Toxicol Sci 2003; 74: 407415.

38. Chen Y, Zuo Z, Chen S, Yan F, Chen Y, Yang Z, et al. Reduction of spermatogenesis in mice after tributyltin administration. Toxicology 2008; 251: 21-27.

39. Kishta O, Adeeko A, Li D, Luu T, Brawer JR, Morales C, et al. In utero exposure to tributyltin chloride differentially alters male and female fetal gonad morphology and gene expression profiles in the Sprague-Dawley rat. Reprod Toxicol 2007; 23: 1-11.

40. Wang BA, Li M, Mu YM, Lu ZH, Li JY. [Effects of tributyltin chloride (TBT) and triphenyltin chloride (TPT) on rat testicular Leydig cells]. Zhonghua Nan Ke Xue 2006; 12: 516519.

41. Yu WJ, Lee BJ, Nam SY, Kim YC, Lee YS, Yun YW. Spermatogenetic disorders in adult rats exposed to tributyltin chloride during puberty. J Vet Med Sci 2003; 65: 1331-1335.

42. Yu WJ, Nam SY, Kim YC, Lee BJ, Yun YW. Effects of tributyltin chloride on the reproductive system in pubertal male rats. J Vet Sci 2003; 4: 29-34.

43. Zhang J, Zuo Z, He C, Wu D, Chen Y, Wang C. Inhibition of thyroidal status related to depression of testicular development in Sebastiscus marmoratus exposed to tributyltin. Aquat Toxicol 2009; 94: 62-67.

44. Zhang J, Zuo Z, He C, Cai J, Wang Y, Chen Y, et al. Effect of tributyltin on testicular development in Sebastiscus marmoratus and the mechanism involved. Environ Toxicol Chem 2009; 28: 1528-1535.

45. Robertson KM, O'Donnell L, Jones ME, Meachem SJ, Boon WC, Fisher CR, et al. Impairment of spermatogenesis in mice lacking a functional aromatase (cyp 19) gene. Proc Natl Acad Sci U S A 1999; 96: 7986-7991.

46. Shetty G, Krishnamurthy H, Krishnamurthy HN, Bhatnagar AS, Moudgal NR. Effect of long-term treatment with aromatase inhibitor on testicular function of adult male bonnet monkeys (M. radiata). Steroids 1998; 63: 414-420.
47. Habenicht UF, Schwarz K, Schweikert HU, Neumann F, el Etreby MF. Development of a model for the induction of estrogen-related prostatic hyperplasia in the dog and its response to the aromatase inhibitor 4-hydroxy-4-androstene3,17-dione: preliminary results. Prostate 1986; 8: 181-194.

48. Suzuki K, Ito K, Tamura Y, Suzuki T, Honma S, Yamanaka H. Effect of aromatase inhibitor, TZA-2209, on the prostate of androstenedione-treated castrated dogs: changes in prostate volume and histopathological findings. Prostate 1996; 28: 328-337.

49. Bouton MM, Pornin C, Grandadam JA. Estrogen regulation of rat prostate androgen receptor. J Steroid Biochem 1981; 15: 403-408.

50. Dhar JD, Mishra R, Setty BS. Estrogen, androgen and antiestrogen responses in the accessory organs of male rats during different phases of life. Endocr Res 1998; 24: 159169.

51. Cooke GM, Forsyth DS, Bondy GS, Tachon R, Tague B, Coady L. Organotin speciation and tissue distribution in rat dams, fetuses, and neonates following oral administration of tributyltin chloride. J Toxicol Environ Health A 2008; 71: 384-395.

52. Golub M, Doherty J. Triphenyltin as a potential human endocrine disruptor. J Toxicol Environ Health B Crit Rev 2004; 7: 281-295.

53. Grote K, Hobler C, Andrade AJ, Grande SW, Gericke C, Talsness CE, et al. Sex differences in effects on sexual development in rat offspring after pre- and postnatal exposure to triphenyltin chloride. Toxicology 2009; 260: 53-59.

54. Harazono A, Ema M, Ogawa Y. Pre-implantation embryonic loss induced by tributyltin chloride in rats. Toxicol Lett 1996; 89: 185-190.

55. Nakanishi T, Nishikawa J, Hiromori Y, Yokoyama H, Koyanagi $\mathrm{M}$, Takasuga $\mathrm{S}$, et al. Trialkyltin compounds bind retinoid $\mathrm{X}$ receptor to alter human placental endocrine functions. Mol Endocrinol 2005; 19: 2502-2516.

56. Ema M, Miyawaki E, Harazono A, Ogawa Y. Effects of triphenyltin chloride on implantation and pregnancy in rats. Reprod Toxicol 1997; 11: 201-206.

57. Harazono A, Ema M, Kawashima K. Evaluation of malnutrition as a cause of tributyltin-induced pregnancy failure in rats. Bull Environ Contam Toxicol 1998; 61: 224-230.

58. Itami T, Ema M, Amano H, Murai T, Kawasaki H. Teratogenic evaluation of tributyltin chloride in rats following oral exposure. Drug Chem Toxicol 1990; 13: 283-295.

59. Ema M, Fukunishi K, Matsumoto M, Hirose A, Kamata E, Ihara T. Developmental toxicity of dibutyltin dichloride in cynomolgus monkeys. Reprod Toxicol 2007; 23: 12-19.

60. Ema M, Arima A, Fukunishi K, Matsumoto M, Hirata-Koizumi $M$, Hirose A, et al. Developmental toxicity of dibutyltin dichloride given on three consecutive days during organogenesis in cynomolgus monkeys. Drug Chem Toxicol 2009; 32: 150-157. 